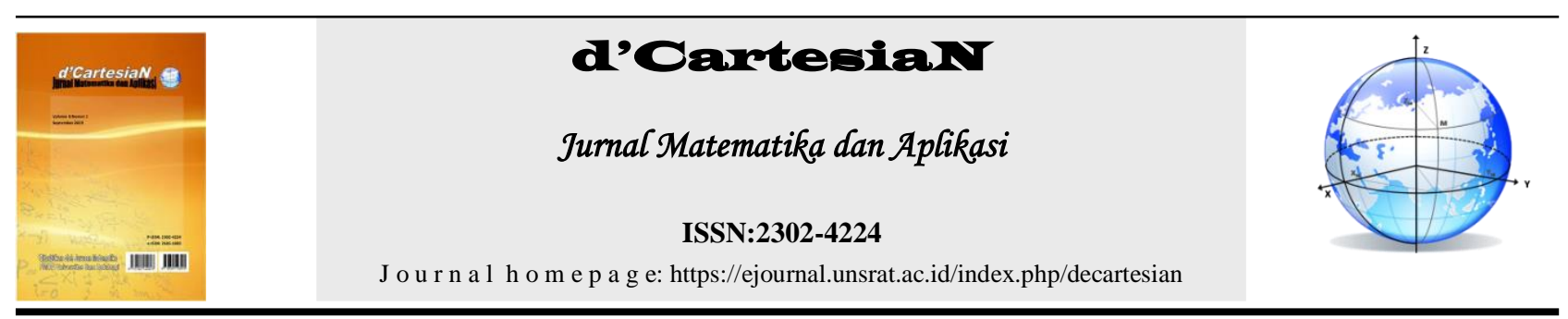

\title{
The Implementation of Bipartite Graph To Minimize Crossing Number Problem of Crossroads In Manado
}

\author{
Timboeleng Axellica Nazareth ${ }^{1}$, Chriestie E.J.C. Montolalu ${ }^{1}$, Benny Pinontoan ${ }^{{ }^{*}}$ \\ ${ }^{1}$ Department of Mathematicss-Faculty of Mathematics and Natural Science-Sam Ratulangi University Manado, Indonesia \\ ${ }^{*}$ Corressponding author : $\underline{\text { bpinonto@yahoo.com }}$
}

\begin{abstract}
A B S T RA C T
In general, the crossroads are the meeting points of two-way roads from four different places. This causes cross direction at that point. There are various methods that can be used to minimize the crossing number problem crossroad, for example graph theory. The ability of graph theory can later help describe crossroads in Manado into graph, with nodes and lines. In this case, the crossing number problems will solve by bipartite graph. Bipartite graph is a graph that does not have an odd cycle, and can be partitioned into two parts of a set of vertices. Based on results of this research, the appropriate form of the bipartite graph is $K_{2,6}$, and $K_{2,5}$ in two different form. First, with an isolated vertex, and second, without isolated vertex. In the case of crossroads, Bipartite graph turns out to be one method that is very suitable and helps determine the crossing number and its solution quickly.
\end{abstract}

\section{ARTICLE INFO}

Received : 13 Juli 2019

Received after revision : 23 Juli 2019

Available online : 25 Juli 2019

\begin{abstract}
A B S T R A K
Secara umum, persimpangan adalah titik pertemuan jalan dua arah dari empat tempat yang berbeda. Hal ini menyebabkan lintas arah pada saat itu. Ada berbagai metode yang dapat digunakan untuk meminimalkan silang arah pada persimpangan, misalnya teori graf. Teori Graf dapat membantu menggambarkan persimpangan jalan di Manado dengan simpul dan garis. Dalam kasus ini, silang arah pada persimpangan akan dipecahkan dengan graf bipartit. Graf bipartit adalah sebuah graf yang tidak memiliki siklus ganjil, dan dapat dipartisi menjadi dua bagian dari sekumpulan simpul. Berdasarkan hasil penelitian ini, bentuk grafik bipartit yang sesuai adalah $K_{2,6}$, dan $K_{2,5}$ dalam dua bentuk berbeda. Pertama, dengan simpul terisolasi, dan kedua, tanpa simpul terisolasi. Dalam kasus persimpangan, grafik bipartit ternyata menjadi salah satu metode yang sangat cocok dan membantu menentukan nomor persimpangan dan solusinya dengan cepat.
\end{abstract}

\section{INTRODUCTION}

Humans are social creatures, and each individual has their own duties and responsibilities. Humans must be socializing, and that does not happen in one place, but various places. that is why various public facilities are held, both personally and by the government. Whether we realize it or not, these facilities are needed because it supports our daily activities, for example offices, schools, libraries, public transportations, even roads.

Roads are public facilities that are always used. This facility needs upgrading and updating both in road maintenance and in its use policies. The road construction is an example of the policy in the use of the road. This policy is regulated by the government, in this case the Public Works Agency (Regional Road) and the Ministry of Public Works (National Road). An example of the construction of the road construction in statement above is the four-way intersection (crossroad).

In general, the crossroads are the meeting points of two-way roads from four different places. This causes cross direction at that point. Various attempts were made to overcome these crossing problems, for example the operation of traffic light and island road construction.

There are various methods that can be used to minimize the crossing number problem of junction, in this case crossroad. Existing methods can also be adapted to education fields. In mathematics, there are many methods that can be used, for example graph theory. The ability of graph theory can later help describe all big crossroad in Manado into graph, with nodes and lines

Graph theory itself is one of the applied theories of classical mathematics which is often used in modeling relevant problems, and is still developing in various representations. This theory was found in solving the river case in Königsberg. Its application is widely used in transportation problems, computer sciences, electrical circuits and others. Applied modeling can be used to solve a problem in the graph. To this day, the graph has many types to be modeled.

Pinotoan and Richter (2004) have conducted a research about Crossing Numbers of Sequences of Graphs in case General Tiles. Consider to the 


\section{The Implementation of Bipartite Graph To Minimize Crossing Number Problem of Crossroads In Manado \\ d’Cartesian : Jurnal Matematika dan Aplikasi, Vol. 8 No. 2 (September 2019): 134-140}

implementation of both graph and crossing numbers in human's life, it required a advance research about it [1].

\section{GRAPH THEORY}

Graph is one of the applied theories of classical mathematics which is still developing until now and is often used in modeling relevant problems. The first problem using graph theory occurred in 1736. The problem was the Koningsberg bridge in the city of Koningsberg (east of Prussia, Germany), now called the city of Kaliningrad, where the Pregal river flowed around the island of Kneiphof and branched into two tributary. Efforts to resolve the problem have been carried out by a Swiss mathematician named L. Euler. He was the first person who managed to find an answer with a simple proof of the model's problem in a graph. Land or points connected by bridges are points called vertices and bridges are lines called sides[2].

Mathematically, Goodaire and Parmenter said that a graph can be denoted by $(V(G), E(G)), V(G)$ whose elements are called vertices and $E(G)$ whose elements are called edges. A graph $G(V, E)$ is a set $V$ of vertices and a subset $E$ of the unordered pairs of (distinct) vertices, called edges. A drawing is a mapping of a graph into a surface. The vertices go into distinct points, called nodes [3].

Geographically, graphs are described as a set of vertex in a two-dimensional plane connected by a set of lines (edges). In other words, if e is the side connecting the vertex $u$ to vertex $v$, then $e$ can be written as $e=$ $(u, v)[4]$.

In an usual graph, vertex might be connected. But the fact is, vertex is not always connected. According to Mardiyono, a node in a graph is not always connected with another node. Such vertices are called isolated vertices or isolated nodes. Isolated vetices are not produce any edges [5].
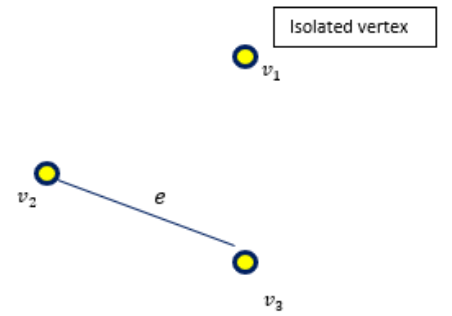

Figure 1. Isolated Vertex

\subsection{Crossing Number}

Assume there is a graph $G$. The crossing number of a graph $G=(V, E)$ is $v(G)=\min \{\operatorname{cr}(D(G)\}$. Similarly, the crossing number $\operatorname{cr}(\mathrm{G})$ is the minimum number of crossings over all drawing of $\mathrm{G}[6]$.

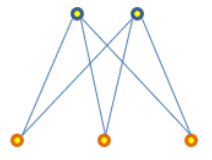

(a)

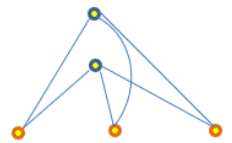

(b)

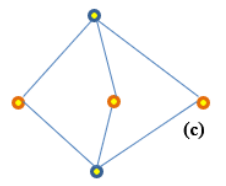

Figure 2. Crossing number of $K_{2,3}$

$$
\text { (a) } C r_{2,3}=3 \text {, (b) } C r_{2,3}=1 \text {, (c) } C r_{2,3}=0
$$

In general, for a graph $G$, the minimum number of pairwise crossings of edges among all drawings of $G$ in the plane is the crossing number of $G$ and is denoted by $\operatorname{cr}(G)$. Thus, $C r_{2,3}=3$. We remark that $C r_{2,3} \leq 3$. It is an interesting exercise for the reader to prove that $\mathrm{Cr}_{2,3}=3$. At present, there is no known efficient algorithm to calculate the crossing number of an arbitrary graph. In fact, the problem of calculating the crossing number of a graph is NPcomplete, so it is unlikely that such an efficient algorithm exists. Yet one might hope that the crossing number of a graph with special structure can be calculated [7].

According to Eades, a precise definition of what is a "good" drawing of a directed graph seems to be difficult to obtain, but the following criteria are generally agreed to be necessary:

C1. Flow should be clearly illustrated.

C2. Nodes should be distributed evenly over the page.

$\mathrm{C}_{3}$. There should be as few arc crossings as possible [8].

\subsection{Bipartite Graph}

A bipartite graph is a graph that does not have an odd cycle, loop, and can be partitioned into two parts of a set of vertices, which is $V_{1}$ and $V_{2}$ [9]. Any subgraph of a complete bipartite graph is called bipartite graph.

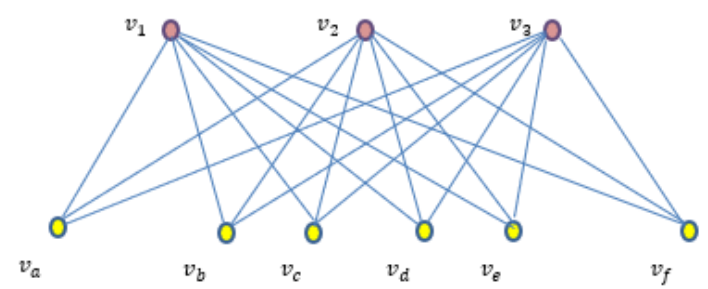

Figure 3. Example of Complete Bipartite Graph

\subsection{Bipartite Crossing Number}

There are only few graphs for which the crossing number is known and hardly any infinite families. The most studied infinite families are the complete graphs, the complete bipartite graphs, the n-dimension cubes, and the cross products of some graphs with a simple structure. However, even for these cases only very partial results are known. In 1970, Watkins introduced a special crossing number for bipartite graphs as an open research problem; the so-called bipartite crossing number [10].

\subsection{Bipartite Crossing Number}

According to Manual Kapasitas Jalan Indonesia (MKJI) 1997, a plot of intersection based on the type of traffic control facility separated into four parts. Two of them are:

1. Signalised Intersection

It is an intersection where the movement or flow of traffic from each approach is regulated by signal lights to pass through the intersection in rotation.

2. Unsignalised Intersection

It is a meeting of roads that do not use signals in their settings [11]. 


\section{RESEARCH METHODOLOGY}

\subsection{Time and Research Place}

This research has been held in Mathematics Departments of Sam Ratulangi University from December 2018 until April 2019.

\subsection{Research Methods}

The method that used in this research is a literature study by studying the literature related to bipartite graph, and crossing number problems.

\subsection{Research Stage}

The steps to be used in completing this research are as follows:

1. Retrieve data in research sources

2. Determine vertex and edges of all critical crossroads throughout Manado, where vertex is the specific path location, and edges are the connected direction of the path.

3. Make a graph based on existing data

4. Determine the bipartite graph of crossroads that possible.

5. Determine the crossing number problem of all critical crossroads throughout Manado.

6. Solve crossing number problems with all possibilities bipartite graphs.

\subsection{Data Analysis}

The data used in this study are:

1. Secondary data, and it was taken from the Manado City Transportation Office Department.

2. Primary data, the data is taken by the researchers themselves by going to the field (including roads recommended by the Department of Transportation)

From the discussion with one of the employees, it was found that the path direction of the vehicle in Manado is based on the meeting result between the mayor of Manado city together with the Manado City Transportation Team. The policy also underlies the formation of a median, even traffic light.

\section{RESULTS AND DISCUSSION}

\subsection{Results}

With $G_{a}$ is a modified $K_{2,6}, \mathrm{G} \_\mathrm{b}$ and $\mathrm{G} \_\mathrm{a}$ is a modified $K_{2,5}$. The remain routes $(3,6$, and 8$)$ are not possible with bipartite graph. So, it will solve only with the ordinary crossing number problem theorem.
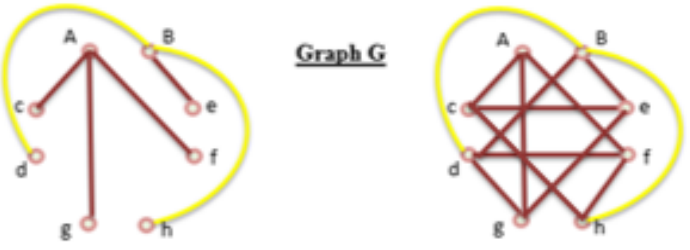

Figure 4. Route 1 solution
Table 1. All Bipartite Graph

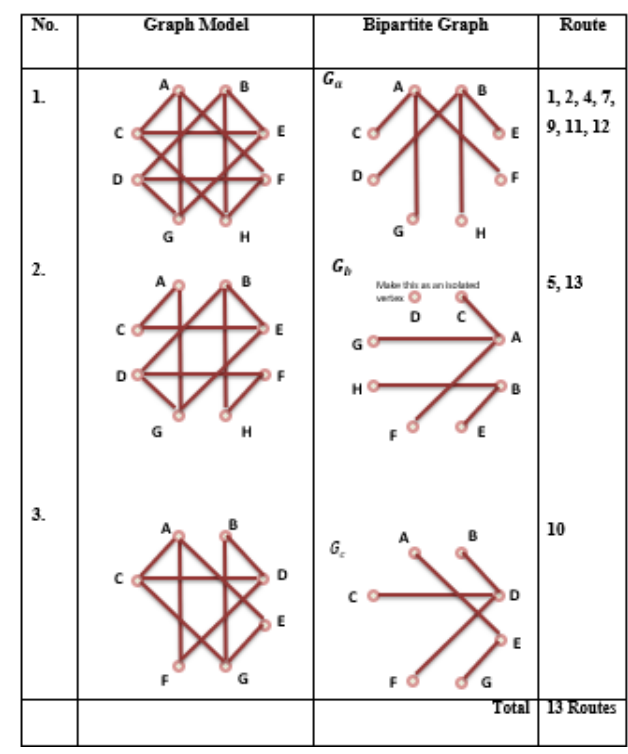

\subsubsection{Route 1}

This crossroad direction is from Malalayang Hospital $(A, B)$, GMIM Bukit Moria Malalayang $(C, D)$, Malalayang Holland Bakery $(E, F)$, and Indomaret Sea Street $(G, H)$. This route cause 12 crossing number problems. To solve this out, take the $K_{2,6}$ form in a possible apply. Applying crossing number problems steps with that bipartite graph, conduced three crossing number problems reduction each possibility.

\subsubsection{Route 2}

This crossroad direction is from Jambore (A,B), GIZI Church (C,D), Kleak (E,F), Freshmart Winangun $(\mathrm{G}, \mathrm{H})$. This route cause 12 crossing number problems. To solve this out, take the $\mathrm{K} \_2,6$ form in a possible apply. Applying the theorem, conduced three crossing number problems reduction each possibility. In other words, to minimize the occurrence of crossing on this road, there are two roads whose path need to change.
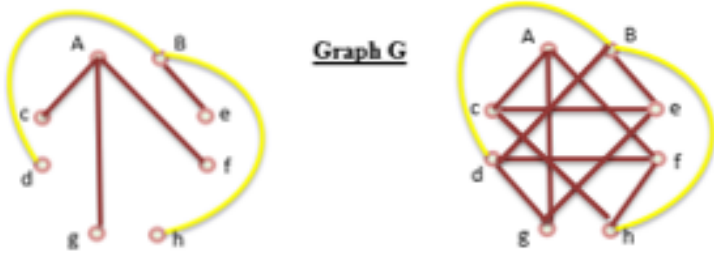

Figure 5. Route 2 solution

\subsubsection{Route 3}

This route cause 1 crossing number problem. The Graph Model for this route is

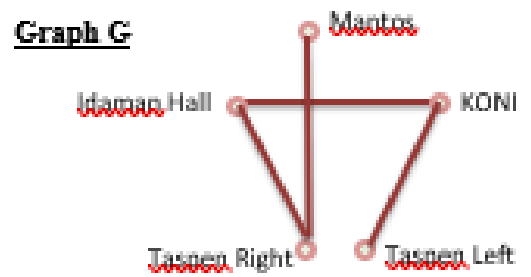

Figure 6. Route 3 Graph 


\section{The Implementation of Bipartite Graph To Minimize Crossing Number Problem of Crossroads \\ In Manado \\ d’Cartesian : Jurnal Matematika dan Aplikasi, Vol. 8 No. 2 (September 2019): 134-140} will be

With crossing number problems steps, the result

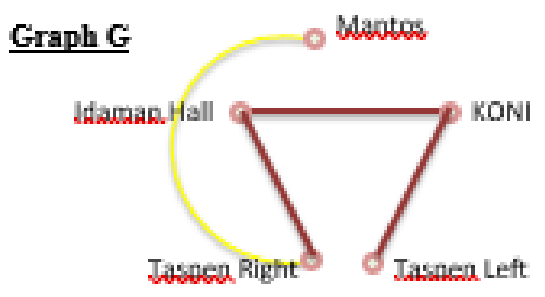

Figure 7. Route 3 solution

\subsubsection{Route 4}

This crossroad direction is from cutting way from Kembang street $(A, B)$, Bethesda chruch $(C, D)$, Siswa street $(E, F), 1^{\text {st }}$ State Senior High School Manado $(G, H)$. This route cause 12 crossing number problems. To solve this out, take the $K_{2,6}$ form in a possible apply. Applying the theorm, conduced three crossing number problems reduction each possibility.
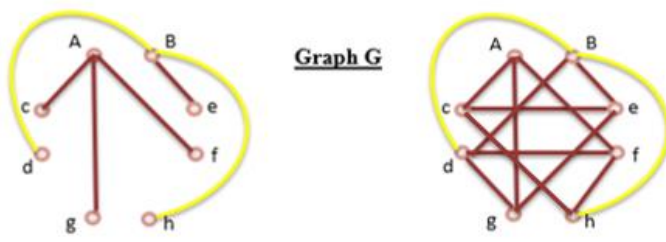

Figure 8. Route 4 solution

\subsubsection{Route 5}

This crossroad direction is from August 17th street (A,B), Manado Post (C,D), Adventist Manado Hospital (E,F), and Provincial Tourism and cultural Services $(\mathrm{G}, \mathrm{H})$. This route cause eight crossing number problems. To solve this out, take the K_2,6 form in a possible apply. Applying crossing number problems steps with that bipartite graph, it possibles to reduce crossing number problems up to five crossings.

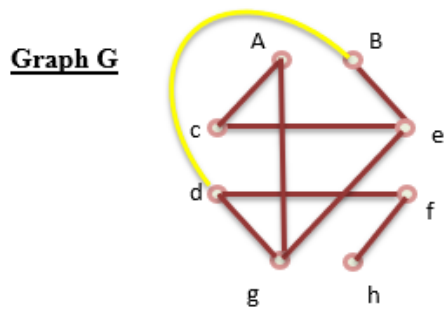

Figure 9. Route 5 solution

\subsubsection{Route 6}

This route cause 1 crossing number problem. The Graph Model for this route is

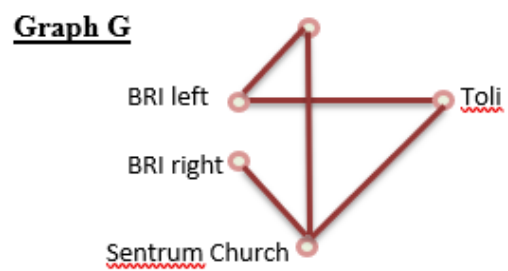

Figure 10. Route 6

This route has no available solution to minimize the crossing number problem. But if the direction from Toli change to left,

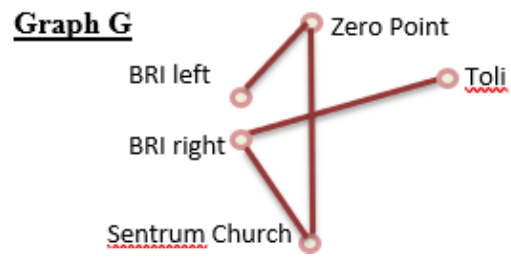

Figure 11. Route 6 suggestion

With crossing number problems steps, then the result will be

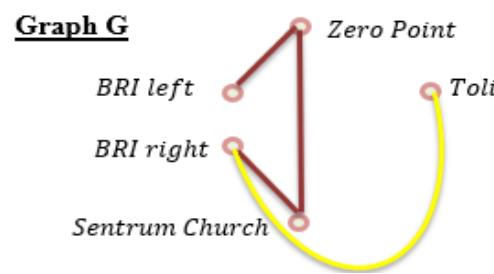

Figure 12. Route 6 solution

\subsubsection{Route 7}

This crossroad direction is from Tikala Gas Station (A,B), Indonesian Biblical Institution Manado (C,D), August $17^{\text {th }}$ street (E,F), and Toar street (G,H). This route cause 12 crossing number problems. To solve this out, take the K_2,6 form in a possible apply. Applying crossing number problems steps with that bipartite graph, conduced three crossing number problems reduction each possibility. In other words, to minimize the occurrence of crossing on this road, there are two roads whose path need to change.
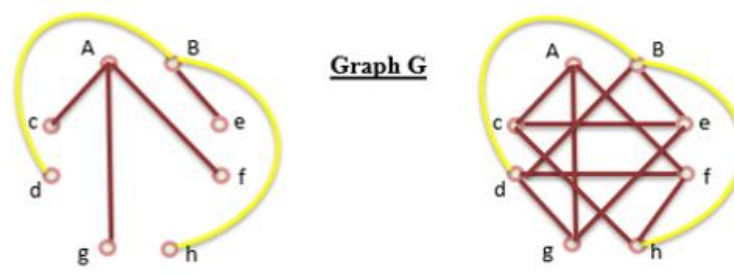

Figure 13. Route 7 solution

\subsubsection{Route 8}

This route cause 1 crossing number problem. The Graph Model for this route is 


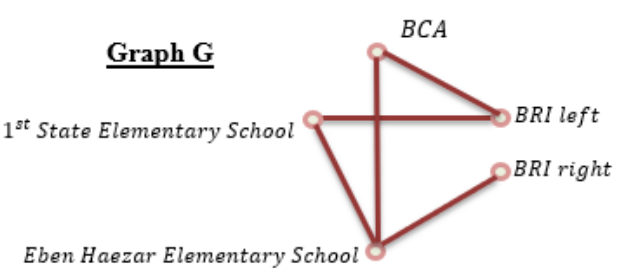

Figure 14. Route 8 will be

With crossing number problems steps, the result

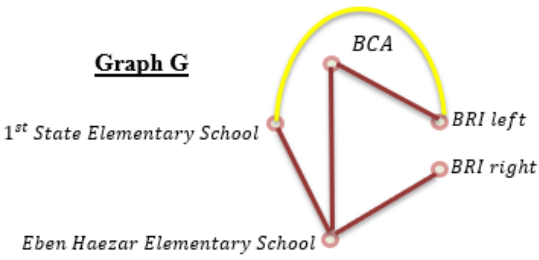

Figure 15. Route 8 solution

\subsubsection{Route 9}

This crossroad direction is from North Sulawesi Province Public Works Service (A,B), TVRI (C,D), Banjer $(\mathrm{E}, \mathrm{F})$, and Pommorow street $(\mathrm{G}, \mathrm{H})$. This route cause 12 crossing number problems. To solve this out, take the $\mathrm{K} \_2,6$ form in a possible apply. Applying crossing number problems steps with that bipartite graph, it possibles to reduce crossing number problems up to nine crossings.

\section{$\underline{\text { Graph G }}$}

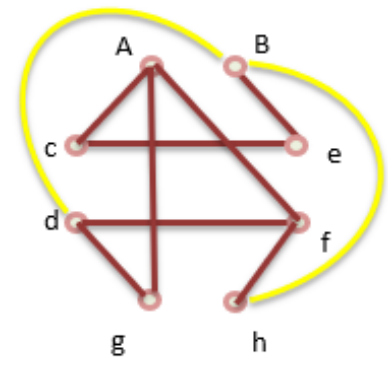

Figure 16. Route 9

\subsubsection{Route 10}

This crossroad direction is from Paal 2 (A,B), Martadinata (C,D), Ranomuut (E,F), and Bus Station (G). This route cause five crossing number problems. To solve this out, take the $\mathrm{K} \_2,5$ form in a possible apply.

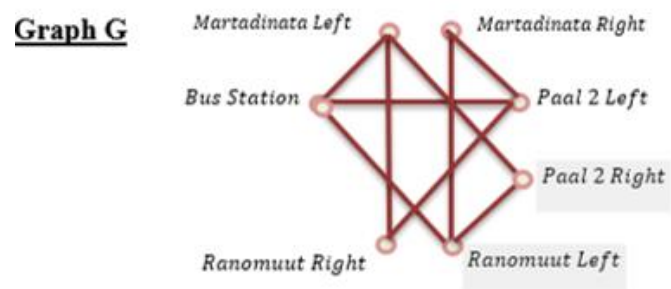

Figure 17. Route 10

With crossing number problems step in $K_{2,5}$ form, it reduces one crossing. So, it remains one crossing.

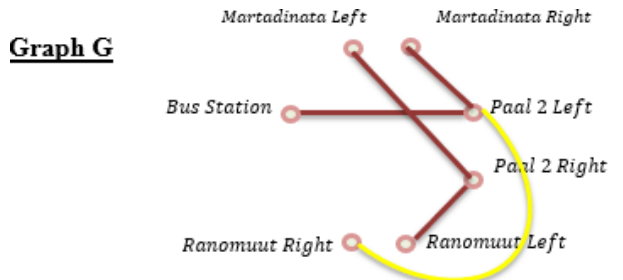

Figure 18. Route 10 solution

\subsubsection{Route 11}

This crossroad direction is from Boulevard 2 (A,B), Main Street (C,D), Tuminting traditional market (E,F), and Mayor Street $(\mathrm{G}, \mathrm{H})$. This route cause 12 crossing number problems. To solve this out, take the $\mathrm{K} \_2,6$ form in a possible apply. Applying crossing number problems steps with that bipartite graph, it possibles to reduce crossing number problems up to nine crossings. So, this graph remains three crossing numbers.

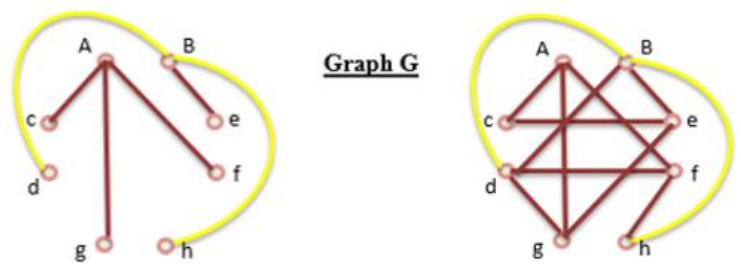

Figure 19. Route 11 solution

\subsubsection{Route 12}

This crossroad direction is from Tuminting traditional market $(\mathrm{A}, \mathrm{B})$, cutting way to Martadinata (C,D), Mayor street (E,F), and Main Street $(\mathrm{G}, \mathrm{H})$. This route cause 12 crossing number problems. To solve this out, take the K_2,6 form in a possible apply. Applying crossing number problems steps with that bipartite graph, it possibles to reduce crossing number problems up to nine crossings. So, this graph remains three crossing numbers.

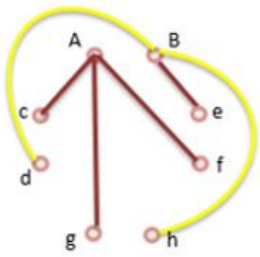

$\underline{\text { Graph G }}$

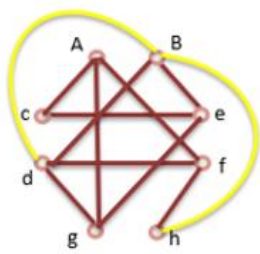

Figure 20. Route 12 solution

\subsubsection{Route 13}

This crossroad direction is Kema (A,B), Transmart Paniki (C,D), Tamansari Metropolitan (E,F), and Interchange $(\mathrm{G}, \mathrm{H})$. This route cause eight crossing number problems. To solve this out, take the $\mathrm{K} \_2,6$ form in a possible apply. Applying crossing number problems steps with that bipartite graph, it possibles to reduce crossing number problems up to five crossings. So, this graph remains three crossing numbers.

\section{$\underline{\text { Graph G }}$}

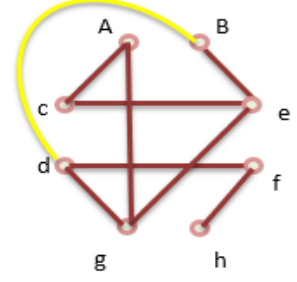

Figure 21. Route 13 solution 


\section{The Implementation of Bipartite Graph To Minimize Crossing Number Problem of Crossroads In Manado \\ d'Cartesian : Jurnal Matematika dan Aplikasi, Vol. 8 No. 2 (September 2019): 134-140}

\subsection{Discussion}

The bipartite graph model can be applied to all four intersection models. However, it needs to see the condition of the crossroad. If only looking at the mathematical side (graph), bipartite graph can reduce some crossing number problems. However, if viewed from the side of the object condition (road), there are some cases that make bipartite graph less effective as a solution to the crossing number problem. An example is the four intersection proposed by one of the examiners, namely the intersection of four Citraland-Ringroad.

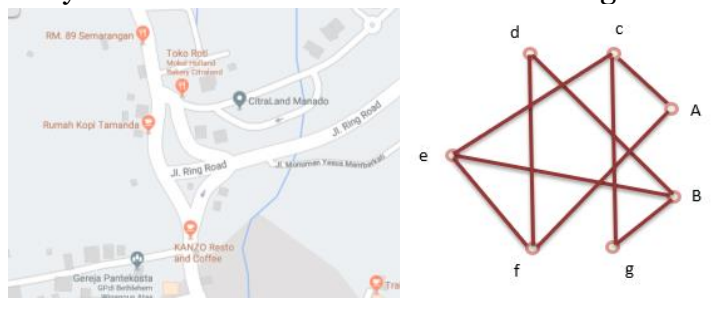

Figure 22. Route Citraland-Ringroad

This crossroad direction is Winangun (A,B), Police station (c,d), Pineleng (e), and Ringroad (f,g). If only considering bipartite graphs, this crossroad crossings can be minimized. But when applied to the state of the object, there is no adequate way as an alternative to prevent crossing. That is why bipartite graph is not an effective theory in this case to minimize the occurrence of crossing number problems.

\section{CONCLUSION AND SUGGESTION}

\subsection{Conclusions}

Based on the results of the study, the appropriate form of the bipartite graph is

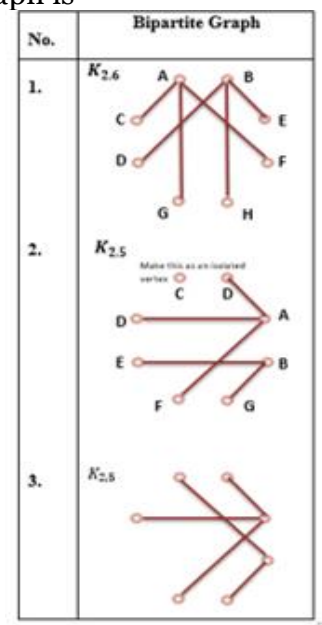

Figure 23. Form of The Bipartite Graph

In the case of crossroads, bipartite graph turns out to be one method that is very suitable for crossing number problems, and helps determine the crossing number and its solution quickly.

\subsection{Suggestion}

The government can consider the use of mathematical methods, especially in the graph field, in solving transportation problems. With the development and correct implementation, and considering more complex factors in terms of relevance, researchers believe that this can have a positive impact.

\section{REFERENCES}

[1] Pinontoan, B., R. Richter. 2003. Crossing Numbers Of Sequences of Graphs II: Planar Tiles. Journal of Graph Theory 42(4):332 - 341.

[2] Munir, R. 2014. Matematika Diskrit Edisi 5 . Penerbit Informatika, Bandung.

[3] Guy, R. 1972. Crossing Number of Graphs. Graph Theory and Application Vol. 303:111-124.

[4] Munir, R. 2016, Matematika Diskrit Revisi Keenam, Penerbit Informatika, Bandung.

[5] Mardiyono, S. 1996. Matematika Diskret, Universitas Negeri Yogyakarta. Yogyakarta.

[6] Munir, R. 2010. Matematika Diskrit. Edisi ke-3. Informatika, Bandung.

[7] Pinontoan, B., W. Weku and J. Rawung. 2013. KCrossing Critical Almost Planar Graphs. Jurnal Ilmiah Sains Vol. 13(1):62-67.

[8] Eades, P., N.C. Wormald. 1994. Edge Crossings in Drawings of Bipartite Graphs. Algorithmica Vol. 11:(379-403).

[9] Abrori, M., R. Wahyuningsih. 2012. Penentuan Matching Maksimum Pada Graf Bipartit Berbobot Menggunakan Metode Hungarian. Jurnal Ilmiah Teknik Industri Vol. 11:(9-21).

[10] May, M., K. Szkatula. 1998. On The Bipartite Crossing Number. Control and Cybernetics Vol. $17: 85-89$

[11] MKJI 1997. 1997. Manual Kapasitas Jalan Indonesia. Kementrian Pekerjaan Umum Republik Indonesia.

Timboeleng Axellica Nazareth (axellicant@gmail.com)

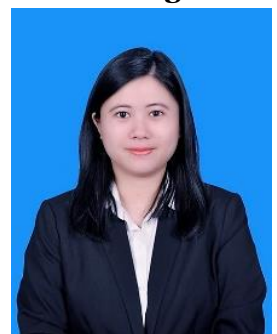
Born in Manado, North Sulawesi on January $12^{\text {nd }}, 1996$. She pursued an higher education in the Mathematics Department, Faculty of Mathematics and Natural Science in Sam Ratulangi University. 2019 is the last year she studied. This paper is the result of a published thesis she researched.

Chriestie E.J.C. Montolalu (Chriestelly@yahoo.com)

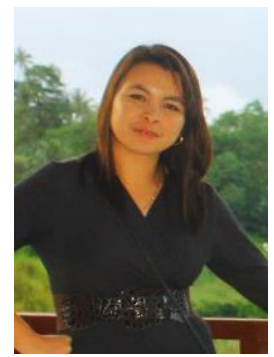
Born at December $10^{\text {th }}, 1985$ Completed his Bachelor's degree in Sam Ratulangi University in 2007. In 2015, she completed his Doctoral degree in University Of Queensland Australia. She works at the Mathematics Study Program in Sam Ratulangi University as a permanent academic lecturer. 
Benny Pinontoan (bpinonto@yahoo.com)

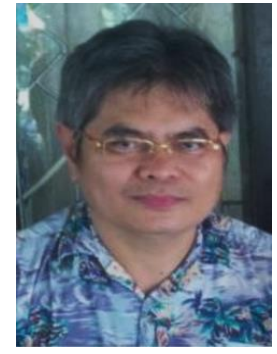

Born in Bitung, North Sulawesi, Indonesia, and lives in Manado.

Completed his Bachelor's degree in

Technische Informatica at Faculteit

Informatica Eindhoven, the

Netherlands in 1993. In 2002 he

completed his Doctoral degree in

Mathematics at School of

Mathematics and Statistics,

Carlethon University Ottwa Canada.

In 1995 he was appointed lecture at Sam Ratulangi

University (UNSRAT) and since 1 March 2006 became a

Profesor of Mathematics at Faculty of Mathematics and

Natural Science, UNSRAT. 